\title{
Peningkatan Kapabilitas Karyawan dan Penerapan Budaya Baru Perusahaan dalam Mewujudkan Daya Saing
}

\section{Improvement of Employee Capability and Application of the Company's New Culture in Realizing Competitiveness Iwan Sudirlan 1*), M. Syamsul Maarif'), Joko Affandi3) \\ \& Yandra Arkeman4)}

2,3) Sekolah Bisnis IPB Bogor

4) Teknologi Industri Pertanian, Fateta IPB, Bogor

*Corresponding author: e-mail: iwansudirlan1967@gmail.com

\begin{abstract}
Abstrak
Lingkungan dunia yang berubah dengan cepat menuntut perusahaan untuk menyesuaikan dengan kondisi yang ada. Perubahan lingkungan yang terjadi meliputi teknologi, sistem informasi, ekonomi dan politik yang menyebabkan munculnya regulasi dan turunan baru sehingga pelaku industri dan industri dalam implementasinya dapat berjalan dengan baik. Salah satu perusahaan telekomunikasi di Indonesia dalam mempertahankan pertumbuhan pendapatan dan laba meningkatkan kemampuan karyawan dan penerapan budaya perusahaan baru dalam mewujudkan daya saing. Visi dan misi berubah dengan transformasi menyeluruh yang lengkap dengan strategi yang terkandung dalam program yang didorong oleh karyawan berdasarkan nilai-nilai perusahaan. Perusahaan dalam periode transformasi dari 2011 hingga 2016 mengadakan survei keterlibatan dengan hasil utama mayoritas pendapat seperti perubahan yang terjadi. Peneliti menggunakan kuesioner metode survei untuk mengumpulkan informasi setelah lahir kembali dari karyawan Indosat Ooredoo sebagai responden yang didistribusikan ke tingkat staf, manajer, kepala divisi, dan kepala kelompok. Metodologi analisis statistik deskriptif digunakan untuk menganalisis informasi yang telah dikumpulkan. Hasil analisis data kuesioner menunjukkan bahwa 7 (tujuh) variabel yang menilai peningkatan kemampuan karyawan dan penerapan budaya baru perusahaan dalam mewujudkan daya saing menunjukkan bahwa tujuh variabel tersebut mempengaruhi tingkat keamanan dan kenyamanan karyawan dan manajemen menengah.
\end{abstract}

Kata Kunci: kapabilitas, budaya, reborn, dan transformasi 


\begin{abstract}
The rapidly changing world environment requires companies to adjust to existing conditions. Environmental changes that occur include technology, information systems, economic and political causes of the emergence of new regulations and derivatives so that industry and industry players in the implementation can run well. One telecommunication company in Indonesia in maintaining revenue and profit growth improves employee capability and application of new corporate culture in realizing competitiveness. A vision and mission change with complete comprehensive transformation with a strategy embodied in employee-driven programs based on company values. The company in transformation years periode from 2011 until 2016 hold engagement survey with main result the majority of opinions like the changes that occur. Researcher use survey method questionnaires to gather information after reborn launched from Indosat Ooredoo employees as respondents that distributed to a level of staff, managers, division heads and group heads. Descriptive statistical analysis methodology is used to analyze information that has been collected. The results data analysis of the questionnaire showed that 7 (seven) variables assessing the improvement of employee capabilities and the application of the company's new culture in realizing competitiveness showed that the seven variables affected the level of security and comfort of employees and middle management.
\end{abstract}

Keywords: capability, culture, reborn, and transformation

How to Cite : Sudirlan Iwan, Maarif M. Syamsul Affandi Joko, dan Arkeman, Yandra (2019). Peningkatan Kapabilitas Karyawan dan Penerapan Budaya Baru Perusahaan dalam Mewujudkan Daya Saing, Jurnal Konsep Bisnis dan Manajemen. 5 (2): 239-256 


\section{PENDAHULUAN}

PT. Indosat Tbk (Indosat Ooredoo) merupakan salah satu perusahaan di Indonesia yang dalam perkembangannya masuk dalam jajaran perusahaan yang terbaik. Sejak tahun 2009 hingga saat ini, kepemilikan saham mayoritas di PT. Indosat Tbk adalah Ooredoo (ex. Qatar Telecom). Seperti pada umumnya pemegang saham mayoritas lebih cenderung mendominasi pengambilan keputusan dalam menjalankan operasional perusahaan, pengelolaan pegawai dan manajemen serta perubahan organisasi karena mereka memiliki suara lebih banyak. Ditambah dengan jumlah modal saham mayoritas yang mengikat di dalam perusahaan publik dan ini terlihat sangat adil untuk pengambilan keputusan, disampaikan dalam artikel law firm (Hardy 2011). Hal ini sepertinya memberikan sumbangan terhadap faktor keamanan dan kenyamanan karyawan dan manajemen menengah walau kebijakan yang digunakan kearah yang lebih baik. Kenaikan gaji dan kompensasi yang lebih baik sebagai salah satu perbaikan sistem, selalu menjadi tidak menarik karena isuisu kesejahteraan lainnya yang muncul.

Di dalam teori motivasi karyawan, mulai dari teori manajemen efisiensi industri oleh Taylor (1911), Maslow
(1943) dan Herzberg (1959) manyatakan bahwa meskipun banyak unsur dari teori ini yang telah mengalami ujian waktu, pengalaman menunjukkan bahwa prinsipprinsip yang mendasari jarang diterapkan secara konsisten atau diterapkan dengan benar. Kasali (2015) berpendapat kapabilitas karyawan akan menjalani tiga ujian sehingga tidak bisa terus berkarir atau menjadi obsolete (using) dan tersingkir. Semua usaha dan industri berevolusi, tak ada lagi yang bertahan bila sekedar transit. SDM pun berevolusi, tidak hanya keterampilan teknis yang berhubungan dengan ilmunya, melainkan juga kecakapan hidupnya.

Indosat Ooredoo melakukan penyesuaian lingkungan eksternal dengan persaingan yang sangat ketat. Indosat Ooredoo tahun 2009 melakukan perubahan, diantaranya mengubah visi dan misi serta nilai-nilai perusahaan. Visi Indosat Ooredoo berubah menjadi "pilihan utama pelanggan untuk seluruh kebutuhan informasi dan komunikasi”. Misi perusahaan berubah menjadi sebagai berikut: (1) menyediakan dan mengembangkan produk, layanan dan solusi inovatif yang berkualitas untuk memberikan nilai lebih bagi para pelanggan; (2) Meningkatkan shareholders value secara terus menerus: 
Mewujudkan kualitas kehidupan yang lebih baik bagi stakeholder. Sedangkan nilai-nilai perusahaan menjadi Trust, Care, Fast, Passion to be the best dan Youthful Spirit. Selama periode transformasi yang dimulai dari tahun 2009 hingga pelaksanaan reborn Indosat Ooredoo di tahun 2015 telah melaksanakan survey engagement (ECHO) dari tahun 2011 hingga tahun 2016 dengan hasil survey yang baik.

Tujuan dari penelitian ini adalah menganalisis perbedaan budaya, perubahan pemegang saham kendali, perubahan plat form cara kerja dan sistem penilaian kinerja karyawan, penempatan karyawan di posisi strategis dari rekrutmen eksternal perusahaan mempengaruhi tingkat keamanan dan kenyamanan karyawan serta manajemen menengah.

\section{METODE PENELITIAN}

Data yang digunakan dalam penelitian ini adalah data primer dan sekuder. Data sekunder dikumpulkan melalui studi literatur, pencarian melalui internet, dan mencari lembaga-lembaga sumber data, seperti Badan Pusat Statistik (BPS), Indosat Ooredoo (terkait dengan profil). Data primer dikumpulkan menggunakan metode survei dengan instrumen pengumpulan berupa kuesioner yang telah disebarkan kepada responden karyawan Indosat Ooredoo dengan tingkatan staf, manajer, kepala divisi dan kepala group. Penentuan sampel ditentukan secara sengaja (purposive sampling), sebanyak 200 kuesioner disebarkan dan diisi oleh 200 responden karyawan, mulai pertengahan Juli 2016. Data hasil kuesioner dianalisis dengan menggunakan metodologi statistika deskriptif dan kualitatif.

\section{HASIL DAN PEMBAHASAN}

Responden pada penelitian ini adalah seluruh karyawan Indosat Ooredoo sebanyak 200 responden mulai dari staff, manajer, kepala divisi, dan kepala group. Hasil analisis terhadap responden menunjukkan bahwa responen lebih banyak laki-laki (63\%) dengan usia 36-40 tahun, bekerja sebagai staff dengan lama pekerjaan lebih dari 15 tahun dan memiliki latar belakang sarjana (S1). Ratarata pengeluaran responden yaitu lima sampai sepuluh juta per bulan.

\section{Penilaian Kapabilitas dan Penerapan Budaya Baru}

Penilaian peningkatan kapabilitas karyawan dan penerapan budaya baru perusahaan dalam mewujudkan daya saing terdiri dari tujuh variabel utama yaitu visi dan misi, budaya perusahaan/organisasi, perubahan saham pengendali, perubahan 
Iwan Sudirlan, Syamsul M. Maarif. Joko Affandi dan Yandra Arkeman : Peningkatan Kapabilitas Karyawan dan Penerapan Budaya Baru Perusahaan dalam Mewujudkan Daya Saing

platform cara kerja dan sistem penilaian kinerja karyawan, SDM/kapabilitas karyawan (rekruitmen karyawan, reward \& punishment, lingkungan kerja, kompetensi karyawan, inovasi \& kreasi karyawan/perusahaan, pelatihan dan pengembangan karyawan/ perusahaan, kebiasaan karyawan/ perusahaan (habbit), infrastruktur, dan iklim perusahaan/organisasi. Hasil analisis sebagai berikut:

\section{Visi dan Misi Perusahaan}

Hasil penelitian menunjukkan bahwa karyawan telah memahami visi dan misi perusahaan dengan baik sebanyak lebih dari $80 \%$, dan menyatakan bahwa visi \& misi perusahaan sudah diasosiasikan dengan baik selaras dengan manajemen perubahan sebanyak $78 \%$, karyawan telah menjalankan visi dan misi dengan baik dan sejalan dengan perubahan dalam mencapai visi hingga lebih dari 70\%. Secara keseluruhan karyawan menjawab setuju dengan rata-rata mencapai sebesar $72 \%$, Perilaku Perusahaan menunjukkan keselarasan antara Visi dan Misi dengan tujuan perusahaan, selalu disempurnakan secara reasonable (masuk akal) dari waktu ke waktu, achievable (dapat dicapai) dari waktu ke waktu, specific (khusus) dari waktu ke waktu, sejalan dengan Visi dan Misi pribadi karyawan sebagai individu yang bekerja di perusahaan ini. Namun tingkat persentase terendah adalah visi dan misi selalu disempurnakan secara timeable (terjadwal) dari waktu ke waktu sebanyak 63\%, dan selalu disempurnakan secara measurable (terukur) dari waktu ke waktu sebanyak $61 \%$.

Hasil penelitian menunjukkan pemahaman karyawan Indosat Ooredoo terhadap visi dan misi perusahaan sudah cukup baik, dan sudah diasosiasikan dengan baik dengan perilaku perusahaan sehingga perubahan yang dilakukan sudah selaras dengan visi dan misi serta tujuan perusahaan. Namun perubahan dan penyempurnaan terhadap visi dan misi yang terjadi belum terjadwal dan terukur dengan baik. Hal yang menarik juga terlihat bahwa visi dan misi perusahaan belum benar-benar sejalan sesuai visi dan misi karyawan Indosat Ooredoo. Artinya Visi dan Misi perusahaan bisa jadi masih belum tersosialisasi dengan kepada karyawan atau dalam penyusunan visi dan misi perusahaan tidak memperhatikan aspek sisi karyawan.

Periode 2004-2006 sampai dengan 2015 Indosat Ooredoo terus mengalami perubahan dan penyesuaian Visi, Misi dan Nilai perusahaan. Perubahan visi, misi dan nilai perusahaan tersebut sesuai denan kebutuhan dan tuntutan organisasi 
maupun tuntutan bisnis modern serta tuntutan daya saing perusahaan. Upaya tersebut menunjukkan bahwa Indosat Ooredoo secara dinamis, konsisten dan terus menerus melakukan perbaikan agar dapat memiliki daya saing yang tinggi. Hal tersebut sejalan dengan yang diungkap oleh Boniface (2011) yang menyatakan bahwa budaya organisasi merupakan komponen penting dalam meningkatkan kinerja dan daya saing oragnisasi. Demikian juga Anand et al. (2009) menyatakan perusahaan yang berhasil senantiasa melakukan perbaikan secara terus menerus.

\section{Budaya Perusahaan/ Organisasi}

Hasil penelitian menunjukkan bahwa karyawan akan berkomitmen kuat dalam pencapaian kinerja sebanyak 92\%, karyawan mengerti bahwa kebutuhan pelanggan merupakan target utama dalam bekerja sebanyak 84\%, menyatakan bahwa perusahaan menjadikan values (trust, care, fast, desire to be the best, youthfull spirit) sebagai budaya perusahaan sebanyak 83\%, karyawan mengetahui target dan job description-nya sebanyak 78\%, Evaluasi kinerja karyawan/staf dilakukan setiap 6 bulan sekali berfokus pada pengembangan SDM berbasis kompetensi sebanyak 77\%, Adanya komunikasi dua arah yang aktif disemua tingkat (karyawan-atasan)

sebanyak 75\%. Secara keseluruhan karyawan menjawab setuju sebesar $67 \%$ bahwa Program Operational Excellent (effisiensi) menjadi prioritas perusahaan, Training untuk peningkatan kapabilitas ditargetkan per karyawan setiap tahun, Ada pelatihan yang telah berhasil dilaksanakan dengan baik untuk memperbaiki core values Perusahaan, Core Values (nilai-nilai) Perusahaan yang telah dirumuskan secara tertulis selalu diterapkan secara konsisten, Manajemen setiap periode triwulan menyampaikan laporan kinerja keuangan perusahaan (misalnya: kinerja saham perusahaan). Namun tingkat persentase terendah adalah menyampaikan laporan kinerja kompetitif perusahaan terhadap pesaing (misalnya: market share) sebanyak 53\%, menyampaikan laporan kinerja kompetitif perusahaan terhadap pesaing (misalnya: strategi berkompetisi dengan kompetitor) sebanyak 51\%, Peningkatan kerja sama tim melalui Achievement Motivation Training dilakukan secara rutin setiap tahun sekali sebanyak 48\%, dan Ide-ide baru dari karyawan yang berkontribusi pada peningkatan kinerja di evaluasi setiap bulan oleh Manajaemen sebanyak $46 \%$.

Dengan demikian, hasil penelitian menunjukkan bahwa karyawan memiliki 
Iwan Sudirlan, Syamsul M. Maarif. Joko Affandi dan Yandra Arkeman : Peningkatan Kapabilitas Karyawan dan Penerapan Budaya Baru Perusahaan dalam Mewujudkan Daya Saing

komitmen yang kuat dalam mencapai karyawan untuk mengatur sendiri kinerja yang tinggi, dengan penyimpanan digital dan metode mengedepankan kebutuhan pelanggan komunikasi tanpa kertas. Guna sebagai target utama dan menjadikan meningkatkan kecepatan dan fleksibilitas, perusahaan sebagai values (trust, care, fast, perusahaan mendorong komunikasi desire to be the best, youthfull spirit), terbuka di semua level, termasuk melalui karyawan juga melakukan pekerjaan grup-grup chatting. Manajemen juga sesuai dengan job description yang telah menggelar forum diskusi rutin dengan ditetapkan dengan melakukan evaluasi para karyawan melalui pertemuan di kinerja setiap 6 bulan sekali sehingga balairung, kunjungan berkala ke kantorterjadi komunikasi dua arah yang aktif di kantor cabang dan lapangan, social semua tingkat. Namun dalam perubahan dan penyempurnaan terhadap budaya perusahaan yang terjadi belum adanya penyampaian laporan kinerja kompetitif perusahaan terhadap pesaing seperti market share dan strategi berkompetisi dengan kompetitor, belum dilakukannya evaluasi terhadap kerja sama tim. Artinya karyawan telah menerapkan budaya perusahaan dengan baik namun belum dilakukan evaluasi terhadap karyawan itu sendiri dan evaluasi terhadap perusahaan kompetitor.

Pada tahun 2015, perusahaan mewujudkan rencana ruang kerja terbuka di sejumlah lantai di gedung kantor pusat Indosat Ooredoo. Dekorasi informal baru berwarna cerah juga dipasang. Selain menekankan mobilitas dan meningkatkan komunikasi, perubahan ini membawa pengaruh dalam mendorong para gathering dengan CEO, serta komunikasi yang teratur dengan perwakilan Serikat Pekerja Indosat Ooredoo (SPI) untuk manfaat bersama.

\section{Perubahan Saham Pengendali}

Hasil penelitian menunjukkan bahwa, sebesar 76\% karyawan/staff mengetahui pemegang saham mayoritas di perusahaan, sebesar 63\% karyawan/Staf mengetahui tentang kepemilikan jumlah persentase saham mayoritas di Perusahaan, sebesar 51\% karyawan faham bahwa perubahan pemegang saham pengendali mempengaruhi Values perusahaan dalam implementasinya di perkerjaan sehari-hari, dan sebesar $44 \%$ karyawan menjawab netral atau 34\% menjawab setuju bahwa Manajemen perusahaan setiap periode triwulan menyampaikan komposisi kepemilikan saham di perusahaan. Namun kalau dilihat 
secara umum, hanya 56\% karyawan yang mengetahui tentang perubahan saham pengendali. Dengan demikian hasil penelitian menunjukkan bahwa perusahaan belum transparan mengenai pemegang saham mayoritas di perusahaan dan kepemilikan jumlah persentase saham mayoritas terhadap karyawan. Artinya perubahan saham pengendali belum seluruhnya diketahui oleh karyawan sehingga dibutuhkan transparansi informasi yang dapat meningkatkan values perusahaan bagi karyawan dalam implementasi pekerjaannya sehari-hari.

Sejak tahun 2009 hingga saat ini, kepemilikan saham mayoritas di Indosat Ooredoo adalah Ooredoo (ex. Qatar Telecom). Seperti pada umumnya pemegang saham mayoritas lebih cenderung mendominasi pengambilan keputusan dalam menjalankan operasional perusahaan, pengelolaan pegawai dan manajemen serta perubahan organisasi karena mereka memiliki suara lebih banyak. Ditambah dengan jumlah modal saham mayoritas yang mengikat di dalam perusahaan publik dan ini terlihat sangat adil untuk pengambilan keputusan, disampaikan dalam artikel law firm (Hardy 2011).

Perubahan Platform Cara Kerja dan Sistem Penilaian Kinerja karyawan
Hasil penelitian menunjukkan bahwa sebesar $87 \%$ setiap 6 bulan sekali perusahaan mengevaluasi pencapaian kerja karyawan, sebesar $86 \%$ setiap 6 bulan sekali para Line manager mengevaluasi kinerja karyawan, sebesar 85\% setiap 6 bulan sekali perusahaan mengevaluasi proses penilaian hasil kerja karyawan, sebesar $81 \%$ setiap tahun seluruh karyawan terlibat dalam survei organisasi sebagai input di dalam pengembangan organisasi. Lebih dari $75 \%$ karyawan setuju bahwa Adanya reward /bonus terhadap hasil pekerjaan yang dilakukan dalam bekerja dan Perusahaan memiliki sistem ERP/SAP yang digunakan untuk menganalisis data kinerja organisasi berjangka waktu 6 bulan. Karyawan setuju Setiap pekerja berpartisipasi dalam timtim improvement sebagai upaya membantu pencapaian target bisnis perusahaan, Line Manager terlibat aktif dalam implementasi HR Sistem untuk mengelola database karyawan yang mendukung evaluasi kinerja tahunan. Kurang dari 50\% karyawan setuju Perusahaan melakukan rekruitmen setiap tahun sejalan dengan implementasi Visi sesuai Program Perusahaan, Perusahaan selalu membandingkan kinerja operasi dengan benchmark ke perusahaan yang memiliki kinerja terbaik dikelasnya, dan 
Iwan Sudirlan, Syamsul M. Maarif. Joko Affandi dan Yandra Arkeman : Peningkatan Kapabilitas Karyawan dan Penerapan Budaya Baru Perusahaan dalam Mewujudkan Daya Saing

Adanya punisment dalam hasil kerja yang tidak sesuai target dari rencana yang diinginkan. Secara keseluruhan karyawan setuju adanya perubahan platform cara kerja dan sistem penilaian kinerja karyawan, walaupun ada juga yang hanya menjawab netral dan sekitar $10 \%$ juga ada yang tidak setuju. Secara keseluruhan karyawan menjawab setuju sebesar 70\%.

Karyawan telah mengetahui platform cara kerja dan sistem penilaian kinerja karyawan yang ditetapkan, namun demikian rekruitmen yang dilakukan oleh perusahaan setiap tahun dan punishment untuk hasil kerja yang tidak sesuai dengan target masih menjadi sedikit masalah bagi karyawan. Artinya bisa jadi rekruitmen yang dilakukan dapat menjadi ancaman bagi karyawan tersebut, dan punishment merupakan suatu momok yang menakutkan bagi karyawan.

\section{SDM - Rekruitment Karyawan}

Penilaian peningkatan kapabilitas karyawan dan penerapan budaya baru perusahaan dalam mewujudkan daya saing pada variabel SDM recruitment karyawan menunjukkan bahwa Sistem rekruitment dilakukan melalui web/online (70\%), Promosi dilakukan berdasarkan kinerja individu bukan pada senioritas karyawan (57\%), dengan rekomendasi dari pihak yang berkompeten (52.1\%). Karyawan setuju adanya sistem rotasi kerja dalam perusahaan sesuai dengan kemampuan karyawan (44\%), jawaban netral dan setuju seimbang pada pernyataan Penempatan posisi karyawan sudah sesuai dengan keinginan karyawan berdasarkan kemampuan yang dimiliki sebesar 41\%, bekerjasama dengan perusahaan lain sebesar 41\%, karyawan menjawab netral mengenai Sistem rekruitment dilakukan bekerjasama dengan universitas sebesar $57 \%$ namun hanya sebesar $18 \%$ saja yang menjawab setuju. Secara keseluruhan karyawan setuju mengenai recruitment karyawan, walaupun ada juga yang hanya menjawab netral dan sekitar 39\% juga ada yang tidak setuju. Secara keseluruhan karyawan menjawab setuju sebesar $46 \%$

Dengan demikian, hasil penelitian menunjukkan bahwa karyawan mengetahui akan adanya rekruitmen yang dilakukan setiap tahun, hal yang menarik adalah tingginya nilai persen karyawan yang tidak setuju terhadap rekruitmen tersebut. Hal ini menunjukkan bahwa perekrutan karyawan baru merupakan ancaman terbesar bagi karyawan yang telah bekerja dengan periode waktu yang lama.

Telah direkrut tenaga profesional berpengalaman dari beragam latar belakang untuk menjalankan unit bisnis 
Digital yang baru. Diharapkan bahwa jaringan dan perspektif holistik yang dimiliki akan mendukung perkembangan bisnis digital serta integrasi konten digital di produk Indosat Ooredoo yang ada. Sejalan dengan penekanan dalam perekrutan karyawan berbakat kuat, Indosat Ooredoo menjadi sponsor utama dalam Diaspora Indonesia ketiga yang diselenggarakan di Jakarta. Pertemuan untuk orang-orang Indonesia yang bermukim di luar negeri ini menjadi kesempatan untuk menyatukan dan menarik orang-orang sangat berbakat. Melalui proses ini, Tim SDM mampu mengidentifikasi dan merekrut kandidatkandidat tertentu yang profilnya sesuai dengan kebutuhan, suatu contoh komitmen dalam merekrut orang berbakat kelas dunia untuk memperkokoh peringkat perusahaan.

\section{SDM - Reward dan Punishment}

Hasil penelitian pada variabel SDM dengan indikator reward and punishment menunjukkan bahwa, Kenaikan upah atau bonus diberikan atas dasar prestasi yang dicapai oleh setiap karyawan (69\%).

Secara keseluruhan imbalan yang diterima karyawan disesuaikan dengan kinerja karyawan (56\%), dan netral terhadap pernyataan Adanya penilaian kinerja yang tidak sesuai/tidak sebanding dengan penilaian objektif (53\%) atau hanya sebesar 33\% yang menjawab setuju. Secara keseluruhan karyawan menjawab setuju sebesar $57 \%$.

Dengan demikian hasil penelitian menunjukkan bahwa karyawan telah memahami adanya reward dan punishment yang dilakukan oleh perusahaan. Semakin tinggi kinerja yang dilakukan oleh karyawan maka upah yang diberikan semakin tinggi, Namun demikian masih terdapat karyawan yang mendapat imbalan bukan dari hasil kinerja melainkan penilaian secara obyektif. Artinya masih belum adanya standar penilaian kinerja yang baku dalam penerapan penilaian kinerja perusahaan.

\section{SDM - Lingkungan kerja}

Lingkungan kerja perusahaan dengan tersedianya klinik dan kondisi kerja yang aman mendapat respon sebesar 95\%, dan lingkungan kerja dengan pencahayaan yang baik sebesar 93\%, lingkungan kerja yang tidak bising, fasilitas kerja yang nyaman dan tata ruang yang nyaman untuk bekerja. Secara keseluruhan karyawan menjawab setuju sebesar $88 \%$. Dengan demikian hasil penelitian menunjukkan bahwa lingkungan kerja saat ini telah memberikan kenyamanan dalam bekerja sehingga dapat meningkatkan kinerja karyawan. Lingkungan kerja merupakan pendorong atau penyemangat karyawan agar dapat bekerja lebih giat 
Iwan Sudirlan, Syamsul M. Maarif. Joko Affandi dan Yandra Arkeman : Peningkatan Kapabilitas Karyawan dan Penerapan Budaya Baru Perusahaan dalam Mewujudkan Daya Saing

dalam rangka meningkatkan kinerja kerja dan melaksanakannya dengan penuh karyawan (Rahmawati et al, 2014).

Pada tahun pertama 2016 setelah tanggung jawab sebesar 85\%. Kemampuan rebranding, Indosat Ooredoo berhasil karyawan dalam mengambil keputusan memanfaatkan jaringan baru yang telah dimodernisasi dan transformasi budaya untuk mencapai pertumbuhan dalam pendapatan, pelanggan, dan cakupan jaringan; menuju pencapaian visi perusahaan sebagai operator digital terkemuka di Indonesia. Perubahanan juga terjadi pada penataan Ruang Kerja di kantor, sehingga lebih elegan dan memberikan kenyamanan kepada para karyawan. Selain itu, perubahan tersebut ditujukan untuk meningkatkan hubungan antar sesama rekan kerja atau dengan atasan dan meningkatkan kepuasan serta kinerja karyawan.

\section{SDM - Kompetensi Karyawan}

Pada variabel SDM dengan indikator kompetensi karyawan diketahui bahwa kemampuan karyawan memahami pekerjaan mendukung program perusahaan dan kemampuan karyawan perusahaan berkoordinasi dengan rekan kerja untuk mencapai tujuan dan target yang ditetapan sebesar 88\%. Setuju bahwa kemampuan karyawan dalam berkomunikasi yang baik dan efektif sebesar 86\%, setuju bahwa kesadaran karyawan untuk mengacu pada prosedur mempercepat program perusahaan, karyawan setuju Pengetahuan anda mengenai perusahaan selalu ter-update untuk mendukung perusahaan. Namun, tingkat persentase terendah adalah karyawan setuju bahwa Uji Kompetensi dilakukan sebagai dasar promosi karyawan (66\%), dan Uji Kompetensi dilakukan sebagai dasar rekruitmen karyawan (60\%). Secara keseluruhan karyawan menjawab setuju dengan modus sebesar 79\%. Menurut Sari et al, 2018) kompetensi memiliki pengaruh positif secara signifikan terhadap kinerja karyawan, semakin tinggi tingkat kompetensi yang dimiliki oleh karyawan pada perusahaan maka akan memberikan kontribusi yang nyata dan signifikan terhadap kinerja pada karyawan tersebut.

Hasil penelitian menunjukkan bahwa pemahaman karyawan terhadap kompetensi karyawan dalam mendukung program perusahaan, dan koordinasi dengan rekan kerja untuk mencapai tujuan dan target yang ditetapkan, serta kemampuan berkomunikasi yang baik dan efektif sudah cukup baik. Namun perubahan dan penyempurnaan terhadap SDM khususnya kompetensi karyawan 
masih belum dapat dioptimalkan jika menggunakan uji kompetensi. Artinya perlu dicarikan alternative lain sebagai dasar promosi dan rekruitmen karyawan.

SDM - Inovasi dan kreasi karyawan/ perusahaan

Pada indikator inovasi dan kreasi karyawan/perusahaan, sebesar $80 \%$ karyawan menginginkan adanya kesempatan dalam berbicara dan membagi ketrampilan dan pengetahuan untuk keberhasilan bersama sebesar $80 \%$. Mengembangkan pemikiran-pemikiran atau gagasan-gagasan baru Anda dan berusaha mencari dan membuat hal-hal baru yang bermanfaat untuk kemajuan perusahaan dan Anda sebesar 78\%. Karyawan setuju Adanya kesempatan ikut serta dalam partisipasi menyampaikan ide-ide sebesar 77\%. Secara keseluruhan karyawan setuju sebesar $77 \%$ bahwa adanya kesempatan mengembangkan kreatifitas, melakukan inovasi produk sesuai dengan modernisasi jaringan, pendidkan merupakan salah satu indikator sebagai kekuatan untuk melakukan inovasi dan perubahan. Hasil ini sejalan yang disampaikan oleh Ompi (2015), dibandingkan dengan provider XL, Indosat Ooredoo lebih unggul dari segi inovasi. Hal ini menunjukkan bahwa Indosat Ooredoo mampu membaca tren yang sedang ramai di pangsa pasar sehingga memunculkan inovasi-inovasi produk/jasa baru. Dengan demikian hasil penelitian menunjukkan bahwa karyawan telah diberikan kesempatan dalam berbicara, mengembangkan pikiran-pikiran atau gagasan-gagasan baru, diberikan kesempatan berpartisipasi. Namun perubahan terhadap SDM dalam bidang inovasi dan kreasi karyawan, kesempatan mengembangkan kreativitas, melakukan inovasi produk sesuai modernisasi jaringan masih menjadi hal yang belum dilakukan oleh perusahaan dan jenjang pendidikan masih menjadi indikator kekuatan dalam melakukan inovasi. Artinya perusahaan harus memberikan kesempatan seluas-luasnya dan sebesarbesarnya bagi karyawan yang mampu menberikan inovasi-inovasi baru bagi perusahaan.

Keberhasilan IM3 Ooredoo dalam membangun loyalitas pelanggan tentunya tidak lepas dari dukungan pihak manajemen melalui perusahaan Indosat Ooredoo yang terus menerus melakukan berbagai inovasi baru terhadap produknya guna tercapainya tujuan dari perusahaan yaitu building customer loyalty di berbagai kalangan (Winarno, 2018).

SDM - Pelatihan dan Pengembangan karyawan/ perusahaan 
Iwan Sudirlan, Syamsul M. Maarif. Joko Affandi dan Yandra Arkeman : Peningkatan Kapabilitas Karyawan dan Penerapan Budaya Baru Perusahaan dalam Mewujudkan Daya Saing

Pelatihan dan pengembangan merupakan hal yang penting dalam peningkatan kapabilitas karyawan dalam mewujudkan daya saing, sebesar 75\% karyawan menginginkan adanya pelatihan untuk meningkatkan pengetahuan karyawan sesuai perkembangan teknologi, Adanya pelatihan memotivasi karyawan, meningkatkan hubungan antar karyawan dan atasan sebesar 67\%, dan adanya kesempatan untuk belajar/kuliah lagi untuk meningkatkan pengetahuan karyawan sebesar 64\%. Semua Departemen melakukan evaluasi Program pelatihan setiap bulan/september/tahun (51\%), Perusahaan memiliki Training Information System (database) untuk perencanaan dan pelaksanaan pelatihan, Karyawan setuju bahwa Kebutuhan pelatihan karyawan di evaluasi setiap bulan berdasarkan prioritas pencapaian KPI (Key Peformance Indicator) utama, jawaban netral dan setuju bahwa Kebutuhan pelatihan karyawan di evaluasi setiap bulan berdasarkan prioritas competency gap (37 dan 40\%), dan tidak setuju sebesar $24 \%$. Secara keseluruhan karyawan menjawab setuju sebesar $56 \%$. Dengan demikian dapat diketahui bahwa karyawan telah mengetahui dan memahami bahwa pelatihan dan pengembangan karyawan sangat dibutuhkan bagi karyawan dalam rangka perubahan perusahaan.

Program pelatihan khusus terkait dengan transformasi perusahaan, seperti pelatihan Indosat Financial Awareness (IFA), diadakan bagi semua karyawan yang memilih tetap bekerja, untuk meningkatkan rasa keberdayaan dan dampak. Pelatihan IFA pertama kali diadakan tahun 2010, dan diadakan kembali pada tahun 2011 dalam skala lebih kecil selaras dengan perubahan kebutuhan dan struktur perusahaan. Secara keseluruhan, pelatihan IFA dirancang untuk meningkatkan kesadaran akan biaya bisnis yang ditimbulkan oleh tindakan masing-masing karyawan, dan menolong karyawan untuk mengkaitkan kegiatan kerja sehari-hari dengan kinerja perusahaan secara keseluruhan, serta menumbuhkan kesadaran transparansi.

\section{SDM - Kebiasaan Karyawan/ Perusahaan} (Habbit)

Hasil penelitian menunjukkan bahwa karyawan setuju mengenai kebiasaan selalu mematuhi perintah untuk melaksanakan tugas yang diberikan oleh atasan dengan baik sebesar 90\%. Karyawan setuju adanya ketika menerima pekerjaan, kemudian Saya kurang memahami pekerjaan tersebut, maka saya akan berdiskusi dengan atasan Saya sebesar 89\%. Karyawan akan bersikap 
kerja berpikir sebelum bertindak sebesar 87\%. Setuju bahwa meningkatkan mutu kerja anda, harus dimulai dengan memperbaiki sikap kerja yang mendahulukan kemajuan perusahaan, kebiasaan pemimpin perusahaan ini sering menekankan pentingnya tugas dengan sebaik-baiknya, kebiasaan pemimpin perusahaan menyampaikan tujuan yang ingin dicapai melakukan pekerjaan sesuai kepribadian diri (misal: bekerja sambil mendengarkan musik, meja kerja yang rapi/berantakan, atau kata-kata motivasi dan tidak setuju sebesar 20\%. Secara keseluruhan karyawan menjawab setuju sebesar 73\%. Namun terdapat jawaban tidak setuju sebesar 51\% mengenai ketika karyawan menerima pekerjaan, namun kurang memahami sehingga harus bertanya kepada atasan.

Dengan demikian dapat diketahui bahwa kebiasaan karyawan dalam perusahaan telah mencerminkan bahwa karyawan tersebut bekerja sesuai dengan perintah atasan dan demi keberlangungan perusahaan. Karyawan dengan kebiasaan yang baik dapat meningkatkan produktivitas dan kinerja karyawan itu sendiri. Indikator ketika menerima pekerjaan, kemudian Saya kurang memahami pekerjaan tersebut, maka saya akan mencoba untuk mengerjakannya tanpa harus bertanya dengan atasan Saya memiliki persen tidak setuju yang tinggi namun demikian hal tersebut menjadi bukan suatu masalah karena dalam bekerja bertanya kepada atasan merupakan suatu hal yang wajar dan dianggap baik.

Indosat Ooredoo merupakan perusahaan multinasional dan merupakan salah satu perusahaan provider terbesar di Indonesia. Salah satu strategi yang digunakan adalah dengan melakukan pengelolaan sumber daya manusia dengan baik. Karena jika sumber daya manusia dalam suatu perusahaan baik maka akan memudahkan perusahaan itu sendiri untuk mencapai tujuannya (Setiawan, 2016).

\section{Infrastruktur}

Hasil penelitian terhadap variabel infrastruktur menunjukkan, Digitalisasi saat ini memerlukan karyawan dengan kemampuan dan knowledge yang sesuai 94\%, Semakin baik tingkat knowledge yang dimiliki karyawan akan membantu untuk melakukan perubahan lebih baik sebesar 93\%, Adanya perangkat komputer on-line yang memudahkan karyawan untuk mengetahui keadaan perusahaan sebesar 89\%, Sarana komunikasi yang modern memudahkan karyawan mencapai kinerja yang optimal di tempat kerja/perusahaan sebesar 88\%, 
Iwan Sudirlan, Syamsul M. Maarif. Joko Affandi dan Yandra Arkeman : Peningkatan Kapabilitas Karyawan dan Penerapan Budaya Baru Perusahaan dalam Mewujudkan Daya Saing

Perusahaan selalu melakukan inovasi mana Indosat Ooredoo menjadi produk untuk dapat bersaing dengan penganjurnya. Sebagai contoh, provider lainnya, Melakukan evaluasi perusahaan mendorong para karyawan secara bertahap dan mengatasi masalah yang tidak menggunakan hak cutinya dengan baik, Adanya media komuniasi untuk beralih ke smartphone 4G internal, baik formal dan informal yang bersubsidi, memberi diskon khusus bagi memadai untuk memastikan karyawan untuk produk tertentu di situs karyawan/staf Direksi berkomunikasi belanja online perusahaan, dan sebagainya. dengan baik satu sama lain sesuai dengan kebutuhan individu dan organisasi, Perubahan Tata Ruang kantor membuat nyaman karyawan yang bekerja, Fasilitas kantor (komputer, software, wi-fi) yang diberikan sesuai dengan perkembangan tahun. Karyawan setuju sebesar 64\% bahwa Teknologi mobile saai ini yang didukung oleh modernisasi jaringan mempengaruhi perekrutan karyawan perusahaan. Secara keseluruhan karyawan menjawab setuju sebesar $83 \%$.

Dengan demikian, penelitian ini menunjukkan bahwa pemahaman karyawan terhadap sarana dan prasarana infrastruktur perusahaan sudah cukup baik. Infrastruktur menjadi variabel penting dalam penilaian peningkatan kapabilitas karyawan, semakin bagus infrastruktur yang disediakan maka meningkatkan kinerja karyawan.

Perusahaan mendorong para karyawan untuk menggunakan teknologi baru dan mengalami gaya hidup digital di Selain itu, para karyawan dari unit-unit bisnis berbeda, termasuk divisi Sumber Daya Manusia, diminta untuk menghadiri rapat komersial, guna memastikan mereka memahami tujuan komersial perusahaan. Semua chief juga diwajibkan berjualan di lapangan, agar mereka memahami dan mengalami sendiri berbagai masalah dan peluang di garis depan. Dengan demikian, dapat ditingkatkan keterlibatan dari berbagai divisi. Secara keseluruhan, sasarannya adalah menciptakan budaya perusahaan yang bergerak cepat, di mana semua kegiatan bisnis diselaraskan dengan tujuan komersial.

\section{Iklim Perusahaan/Organisasi}

Iklim perusahaan/organisasi

adalah persepssi anggota organisasi dan mereka berhubungan secara tetap dengan organisasi mengenai apa yang ada atau terjadi di lingkungan internal organisasi secara rutin yang mempengaruhi sikap dan perilaku organisasi dan kinerja anggota 
organisasi yang kemudian menentukan kinerja organisasi (Wirawan, 2007). Hasil penelitian menunjukkan bahwa, sebesar 78\% karyawan setuju bahwa Perusahaan setiap tahun melakukan team building/outing/out ward bound lintas departemen maupun internal departemen untuk melibatkan karyawan secara aktif terhadap transparan untuk mendorong perubahan yang lebih baik (60\%). Pengelolaan biaya yang rendah/menekan biaya serendah rendahnya sesuai tujuan perusahaan agar perusahaan mampu bersaing (55\%). Manajemen pengadaan Forum Komunikasi Manajemen Pekerja setiap triwulan yang bertujuan untuk mendapatkan umpan balik dari karyawan yang dipergunakan untuk mempertahankan momentum perubahan, karyawan setuju bahwa Target bergerak (moving targets) di evaluasi setiap bulan sekali dengan melibatkan semua manajer departemen. Sebesar $47.9 \%$ karyawan setuju bahwa Setiap ada permasalahan, karyawan dapat menyampaikan secara langsung ke pimpinan/CEO perusahaan. Secara keseluruhan karyawan menjawab setuju sebesar 57\%. Dengan demikian, penelitian menunjukkan bahwa iklim perusahaan yang kondusif, suasana kerja yang nyaman, transparansi dan keterbukaan perusahaan mampu meningkatkan kinerja dan produktivitas karyawan

\section{SIMPULAN}

Hasil penelitian dari tujuh variabel penilaian peningkatan kapabilitas karyawan dan penerapan budaya baru perusahaan dalam mewujudkan daya saing menunjukkan bahwa tujuh variabel tersebut mempengaruhi tingkat keamanan dan kenyamanan karyawan serta manajemen menengah. Visi, misi dan nilai perubahan perusahaan senantiasa mengalami perubahan semenjak periode 2004-2006 hingga 2015, upaya tersebut menunjukkan bahwa Indosat Ooredoo secara dinamis, konsisten dan terus menerus melakukan perbaikan agar dapat memiliki daya saing yang tinggi. Hal serupa dilakukan juga pada rekrutmen karyawan dengan melakukan rekrutmen terhadap tenaga profesional berpengalaman dari beragam latar belakang untuk menjalankan unit bisnis Digital yang baru. Manajamen memberi masukan ke pihak manajemen Ooredoo Pusat agar mengurangi intervensi operasional yang dapat menimbulkan ketidaknyamanan bagi biaya serendah- 
Iwan Sudirlan, Syamsul M. Maarif. Joko Affandi dan Yandra Arkeman : Peningkatan Kapabilitas Karyawan dan Penerapan Budaya Baru Perusahaan dalam Mewujudkan Daya Saing

rendahnya sesuai tujuan agar Perusahaan mampu bersaing (55\%). Manajemen pengadaan Forum Komunikasi Manajemen Pekerja setiap triwulan yang bertujuan untuk mendapatkan umpan balik dari karyawan yang dipergunakan untuk mempertahankan momentum perubahan, karyawan setuju bahwa Target bergerak (moving targets) di evaluasi setiap bulan sekali dengan melibatkan semua manajer departemen. Sebesar $47.9 \%$ karyawan setuju bahwa Setiap ada permasalahan, karyawan dapat menyampaikan secara langsung ke pimpinan/CEO perusahaan. Secara keseluruhan karyawan menjawab setuju sebesar 57\%. Dengan demikian, penelitian menunjukkan bahwa iklim perusahaan yang kondusif, suasana kerja yang nyaman, transparansi dan keterbukaan perusahaan mampu meningkatkan kinerja dan produktivitas karyawan.

\section{DAFTAR PUSTAKA}

Anand G, Peter T, Mohan VW, Tatikonda, Schilling DA. 2009. Dynamic capabilities through continuous improvement infrastructure. University of Illinois. Journal of Operations Management

Boniface C, Madu. 2011. Organization culture as driver of competitive advantage. Journal of Academic and Business Ethics. Canyon (US): Grand Canyon University.

Herzberg, 1959. The Motivation to Work. New York: John Willey and Sons.

Ompi P, Budiasih IGAN. 2015. Analisis Perbandingan Kinerja Perusahaan dengan
Metode Balance Scorecard pada Indosat dan XL. E-Jurnal Akuntansi Universitas Udayana. 10 (1): 31-46.

Rahmawati NP, Swasto B, Prasetya A. 2014. Pengaruh Lingkungan Kerja terhadap Kinerja Karyawan. Jurnal Administrasi Bisnis. 8 (2): 1-9

Sari RN, Sjaharuddin, Razak N. 2018. Pengaruh Kompetensi terhadap Kinerja Dimoderasi Profesionalisme Karyawan. Jurnal Organisasi dan Manajemen. 1: 19-30. DOI: 10.31227/osf.io/nw2ed

Setiawan AA. 2016. Analisis Manajemen Sumber Daya Manusia PT. Indosat Ooredoo. [internet] Diakses pada 05 Januari 2019. Tersedia pada https://www.researchgate.net/publication/ 302385001_Analisis_Manajemen_Sumber_D aya_Manusia_PT Indosat_Ooredoo.

Taylor, Frederick W. 1911. The Principles of Scientific Management. New York: Harper \& Row

Winarno, SH. 2018. Faktor-faktor Penentu Pengaruh Kualitas Produk dan Harga terhadap Loyalitas Pelanggan Indosadvantage. Journal of Academic and Business Ethics. Canyon (US): Grand Canyon University.

Herzberg, 1959. The Motivation to Work. New York: John Willey and Sons.

Ompi P, Budiasih IGAN. 2015. Analisis Perbandingan Kinerja Perusahaan dengan Metode Balance Scorecard t dan XL. E-Jurnal Akuntansi Universitas Udayana. 10 (1): 3146.

Rahmawati NP, Swasto B, Prasetya A. 2014. Pengaruh Lingkungan Kerja terhadap Kinerja Karyawan. Jurnal Administrasi Bisnis. 8 (2): 1-9

Sari RN, Sjaharuddin, Razak N. 2018. Pengaruh Kompetensi terhadap Kinerja Dimoderasi Profesionalisme Karyawan. Jurnal Organisasi dan Manajemen. 1: 19-30. DOI: 10.31227/osf.io/nw2ed

Setiawan AA. 2016. Analisis Manajemen Sumber Daya Manusia PT. Indosat Ooredoo. [internet] Diakses pada 05 Januari 2019. Tersedia pada https://www.researchgate.net/publication/ 302385001_Analisis_Manajemen_Sumber_D aya_Manusia_PT Indosat_Ooredoo.

Taylor, Frederick W. 1911. The Principles of Scientific Management. New York: Harper \& Row

Winarno, SH. 2018. Faktor-Faktor Penentu Pengaruh Kualitas Produk dan Harga terhadap Loyalitas Pelanggan Indosat IM3 
OOREDO0. Jurnal Ekonomi dan Ekonomi Syariah. 1(2): 1-7.

Wirawan. 2007. Budaya dan Iklim Organisasi. Jakarta (ID): Salemba Empat 